\title{
Abdominal aortic aneurysm: while there is still no cure, the key question is which patients to select for intervention and which intervention to select!
}

\author{
Aneurisma da aorta abdominal: enquanto a cura não vem, a seleção do paciente para \\ intervenção e qual intervenção é a questão!
}

Erasmo Simão da Silva*

In 1952, Dubost et al. ${ }^{1}$ began the era of effective repair of aneurysms of the infrarenal aorta using homologous cadaveric aorta grafts, after aneurysmectomy. Development of arterial substitutes, more rigorous surgical techniques, better understanding of the disease, and the advent of ultrasonography which increased diagnoses and perfected preoperative, intraoperative (anesthesia) and postoperative clinical control, surgery for infrarenal aneurysms came to be routine and results became ever more encouraging. The prospect of effective treatment began to raise doubts with relation to which patients with asymptomatic aneurysms were suitable candidates for treatment. An understanding of the natural history of the disease became indispensable and many studies were conducted to investigate this subject.

As the number of patients operated increased, it became clear that, although mortality rates linked to elective conventional surgery exhibited a reduction over the years ( $17.4 \%$ to $5.0 \%$ in 20 years, ${ }^{2}$ between $2.5 \%$ and $3.5 \%$ in Brazil), ${ }^{3-5}$ mortality from ruptured aneurysms remained elevated (over 50\%). ${ }^{6}$ This finding led to an aggressive approach to treatment of aneurysms, with surgery prescribed even for low risk patients, the elderly and patients with aneurysms considered to be small. ${ }^{7,8}$ While this approach does eliminate the possibility of rupture in these patients, a considerable contingent of individuals, with small aneurysms, would be subjected to major surgical operations, which are never risk free and may be unnecessary, since many aneurysms remain stable $e^{9,10}$ and $75 \%$ of people who have aneurysms die of other diseases, ${ }^{11}$ in particular cardiovascular conditions.

It therefore became imperative to establish which patients are at greater risk of aneurysm rupture, in other words, which factors influence rupture of infrarenal aortic aneurysms.

Estes $^{12}$ reported in 1952 that the primary cause of death among patients with abdominal aneurysms was rupture and, in second place, coronary disease. In 1962 , Shatz et al. ${ }^{13}$ recorded a reduction in the number of ruptures, associated with the spread of surgical treatment of aneurysms. These authors considered aneurysms with a maximum transverse diameter of up to $7.5 \mathrm{~cm}$ to be small. These observations were corroborated by Szilagui et al. in $1966,{ }^{14}$ who claimed that surgical repair of aneurysms resulted in equal survival to that observed in the normal population and recommended surgical treatment when the maximum aneurysm diameter reached $6.0 \mathrm{~cm}$. Hollier et al. ${ }^{15}$ demonstrated that coronary disease limited survival of patients after aneurysm repair.

Currently, there is consensus that the single most important risk factor for rupture of an abdominal aortic aneurysm (AAA) is its maximum transverse diameter and this is therefore the factor that is most often used when prescribing surgery. Analysis of several different studies showed that larger aneurysms are more prone to rupture than those with smaller diameters. ${ }^{9,16}$

Controlled studies ${ }^{17,18}$ concluded that aneurysms with largest diameters of up to $55 \mathrm{~mm}$ in men and up to $50 \mathrm{~mm}$ in women have low rates of rupture. The threshold diameter for indication of interventions was therefore defined. However, other studies recommended that aneurysms from 4.0 to $5.0 \mathrm{~cm}$ should also be candidates for surgery, ${ }^{7,8}$ justifying this by the low mortality rates of elective surgery and the high mortality related to rupture.

It was against this backdrop that, from 1991 onwards, an important new factor began to make its own contribution to increasing the debates and controversy related to AAA: endovascular aneurysm repair (EVAR). It has been proven that this procedure offers favorable mortality and morbidity compared with traditional open repair, both during the perioperative period and during short-term patient follow-up. ${ }^{19-21}$ However, over the long-term EVAR has exhibited a higher incidence of failures with 
more frequent need for reoperation and a worrying number of ruptures. ${ }^{22-24}$ Added to this is the daunting requirement for follow-up with tomographic imaging studies, immediately and over the medium and long term. However, the discussion appears far from over because endoprostheses are always in a constant state of development and are achieving ever better long-term results. Technical developments are a challenge to randomized studies because by the time the results are published, the prosthesis, the technique and the experience have all moved on, reducing the study's external validity. ${ }^{25}$ In turn, diagnostic imaging methods for monitoring progress have also improved and follow-up is already being conducted using Doppler ultrasonography, Doppler ultrasonography with contrast and, just beginning, 3-D Doppler ultrasonography. ${ }^{26,27}$

Once more, selection of patients for intervention (endovascular or conventional) or observation can be based on a greater quantity of information and has become even more controversial.

Two features that are invariably highlighted are patients' clinical risk and the anatomy of the AAA, with relation to the neck and the iliac vessels. A patient with favorable anatomy and high risk should be selected for EVAR. A patient with low risk and unfavorable anatomy should be prescribed traditional open repair. But what is low and high risk? What is an unfavorable anatomy? These are concepts that are difficult to apply in real life. More and more often, endoprostheses are being employed outside of the applications in their Information for Use documentation..$^{28}$ Ask a young vascular surgeon fresh out of residency. What would he tend to choose for AAA repair, bearing in mind that during his training he observed that 60 to $75 \%$ of AAAs are repaired by EVAR? With which technique can he explore the limits? Is he subject to a conflict of interests when choosing between one or another endoprosthesis? The patient is informed about techniques and already has a preference. Would the young surgeon know how to deal with this? In short, would he do what is best for the patient or what is 'modern'? Would he do what the patient requests or, rather, what the industry dictates?

Studies show that EVAR has better outcomes when used to repair small aneurysms, because of less remodeling of the aneurysm sac, when compared with large aneurysms..$^{29}$ It is important to observe that, as the aneurysm grows in diameter it loses its proximal and distal necks and progresses to involve the iliac vessels,${ }^{30}$ limiting use of EVAR. However, in countries whose health services map their populations, the number of patients selected for repair could double if the maximum diameter lower cutoff for indicating intervention for AAAs were to be reduced..$^{31,32}$ The impact of the cost of such a policy is obvious. ${ }^{33}$

Considering that just $25 \%$ of aneurysms that are detected do actually rupture, ${ }^{11,34}$ it is clear that the most obvious option would be to identify which patients are candidates for this outcome.

Large transverse diameter is not an excellent indicator of rupture, since there are small AAAs that rupture and large ones that remain intact.

Analysis of the risk factors of rupture is important and should not be undervalued. The following predisposing situations have been identified:

- Young patients;

- Women;

- Active smokers;

- Patients with family history;

- Severe hypertension;

- Patients with COPD;

- Non-diabetics.

These factors are important, but are not sufficient to determine indications, because people who are at high risk from intervention may have all of these risk factors and yet the risks may still outweigh the benefits.

From a biomechanical point of view, an AAA ruptures when, at a given point in the wall, resistance reduces below the tension exerted against it.

Studies that have analyzed and calculated stress against the walls of AAAs, with a view to substituting diameter as a criterion for intervention, are very far from perfect although they have great appeal in terms of publication and dissemination in the medical world. ${ }^{35,36}$ In order to perform this calculation, three types of information are needed: the geometry of the AAA/thickness of the wall, the forces acting and counteracting against the wall and, finally, information about the mechanical properties of the wall. To date, AAA geometry has been based on tomography or magnetic resonance imaging; it is possible that in future 3-D Doppler USG will be used. The thickness of the wall cannot be measured on an individual basis with any clinically applicable method currently available and so a constant thickness ( 15 to $25 \mathrm{~mm}$ ) is used in the stress calculation. The forces acting against the wall are based on arterial blood pressure, but the counteracting forces, exerted by the retroperitoneum and neighboring organs cannot be measured. In the field of the mechanical properties of the wall, Doppler ultrasonography can measure displacement of the wall (strain) in biplanar mode. 
Destructive methods used on specimens taken from people during operations are limited to samples from the anterior surface of the aneurysm, from a more complex whole. Samples of AAAs removed from cadavers make it possible to study several segments, but not all, using uniaxial or biaxial destructive testing (on a structure that is subject to multi axial forces). ${ }^{37,38}$ There are, therefore, severe limitations to knowledge about the biomechanical properties of the walls of AAAs.

In addition to these mechanical aspects of what is an entirely heterogeneous structure, there is also the question of mechanobiology, i.e., how the thrombus interacts with the wall. Does this thrombus protect the AAA from rupture or help to degrade still further the already destroyed wall? ${ }^{39}$ Does it interfere with proteolytic enzymes - elastases and collagenases - and their inhibitors, ${ }^{40}$ with the genetic expression of repair proteins, and with flow characteristics and their cellular interaction on remodeling of the wall? ${ }^{41}$

When imaging methods provide information on the thickness of the entire aneurysm (including points of weakness: blebs) and the mechanical properties of the entire three-dimensional volume of the AAA, it will become possible to improve the equations for calculating risk of rupture, but they are unlikely ever to be infallible. Until this is achieved, or a cure for the disease is found, selection of candidates for intervention and selection of which type of intervention appear to be the guarantee of good quality individual care and of the credibility and viability of the healthcare system in this area.

\section{REFERENCES}

1. Dubost C, Allary M, Oeconomos N. Resection of aneurysm of the abdominal aorta: reestablishment of the continuity by preserved human arterial graft, with result after 5 months. Arch Surg. 1952;64(3):405-8. http://dx.doi.org/10.1001/ archsurg.1952.01260010419018

2. Thompson JE, Hollier LH, Patman RD, Persson AV. Surgical management of abdominal aortic aneurysms: factors influencing mortality and morbity: 20 year experience. Ann Surg. 1975;181(5):654-61. http://dx.doi. org/10.1097/00000658-197505000-00020

3. Bechara MJ, Langer B, Malavolta LC, Kusniec S, Andrade MFC, Presti $C$, et al. Tratamento cirúrgico eletivo do aneurisma da aorta abdominal. Cir Vasc Angiol. 1993;9:35.

4. Bonamigo TP. Tratamento de urgência nos aneurismas da aorta abdominal. In: Bonamigo TP, Burihan E, Cinelli $M$ Jr, Ristow A. Doenças da aorta e seus ramos. São Paulo: Fundo Editorial BYK; 1991. p. 48-58.

5. Becker M, Bonamigo TP, Faccini FP. Avaliação da mortalidade cirúrgica em aneurismas infra-renais da aorta abdominal. J Vasc Bras. 2002;1(1):15-21.
6. Hollier LH, Taylor LM, Ochsner J. Recommended indications for operative treatment of abdominal aortic aneurysms: report of a subcommittee of the Joint Council Of the Society for Vascular Surgery and the North American Chapter of the International Society for Cardiovascular Surgery J. Vasc. Surg. 1992;15(6):104656. http://dx.doi.org/10.1016/0741-5214(92)90462-H

7. Katz DA, Cronenwett JL. The cost-effectiveness of early surgery versus watchful waiting in the management of small abdominal aortic aneurysms. J. Vasc. Surg. 1994;19(6):980-91. http://dx.doi. org/10.1016/S0741-5214(94)70209-8

8. McCabe CJ, Coleman WS, Brewster DC. The advantage of early operation for abdominal aortic aneurysm. Arch Surg. 1981:116(8):1025-9. PMid:7259506. http://dx.doi.org/10.1001/ archsurg.1981.01380200033006

9. Guirguis EM, Barber GG. The natural history of abdominal aortic aneurysms. Am J Surg. 1991;162(5):481-3. http://dx.doi. org/10.1016/0002-9610(91)90266-G

10. Gllmäker H, Homberg L, Elvin A, Nybacka O, Björck CG, Eriksson I. Natural history of patients with abdominal aortic aneurysm. Eur J Vasc Surg. 1991;5(2):125-30. http://dx.doi.org/10.1016/ S0950-821X(05)80675-9

11. Darling RC, Messina CR, Brewster DC, Ottinger LW. Autopsy study of unoperated abdominal aortic aneurysm: the case for early resection. Circulation. 1977;56(Suppl 3):161-4.

12. Estes JE Jr. Abdominal aortic aneurysm: a study of one hundred and two cases. Circulation. 1950;2(2):258-64. http://dx.doi. org/10.1161/01.CIR.2.2.258

13. Schatz IJ, Fairbairn JF, Juergens JL. Abdominal aortic aneurysms: a reapprisal. Circulation. 1962;26:200-5. http://dx.doi. org/10.1161/01.CIR.26.2.200

14. Szilagui DE, Smith RF, De Russo FJ, Elliot JP, Sherrin FW. Contribuition of abdominal aortic aneurysmectomy to prolongation of life. Ann Surg. 1966;164(4):678-99. http://dx.doi. org/10.1097/00000658-196610000-00014

15. Hollier LH, Plate G, O’Brien PC, Kazmier FJ, Gloviczki P, Pairolero PC, et al. Late survival after abdominal aortic aneurysm repair: influence of coronary artery disease. J Vasc Surg 1984;1(2):290-9. http://dx.doi.org/10.1016/0741-5214(84)90060-0

16. Nevitt MP, Ballard DJ, Hallet JW Jr. Prognosis of abdominal aortic aneurysms: a population-based study. N. Engl. J. Med. 1989;321(15):1009-14. PMid:2674715. http://dx.doi.org/10.1056/ NEJM198910123211504

17. Powell JT. Mortality results for randomized controlled trial of early elective surgery or ultrasonographic surveillance for small abdominal aortic aneurysms. The UK Small Aneurysm Trial Participants. Lancet. 1998;352(9141):1649-55. http://dx.doi. org/10.1016/S0140-6736(98)10137-X

18. Lederle FA, Wilson SE, Johnson GR, Reinke DB, Littooy FN, Acher $\mathrm{CW}$, et al. Immediate repair compared with surveillance of small abdominal aortic aneurysms. N Engl J Med. 2002;346(19):143744. PMid:12000813. http://dx.doi.org/10.1056/NEJMoa012573

19. Greenhalgh RM, Brown LC, Kwong GPS, Powell JT, Thompson SG, EVAR Trial Participants. Comparasion of endovascular aneurysm repair in patients with abdominal aortic aneurysm (EVAR trial 1), 30-day mortality results: randomized controlled trial. Lancet. 2004;364(9437):843-8. http://dx.doi.org/10.1016/ S0140-6736(04)16979-1

20. Prinssen M, Verhoeven ELG, Buth J, Cuypers PWM, Van Sambeek MRHM, Balm R, et al. A randomized trial comparing conventional and endovascular repair of abdominal aortic aneurysms. $\mathrm{N}$ Engl J Med. 2004;351:1607-18. PMid:15483279. http://dx.doi. org/10.1056/NEJMoa042002 
21. Stroupe KT, Lederle FA, Matsumara JS, Kyriakides TC, Jonk YC, $\mathrm{Ge} L$, et al. Cost-effectiveness of open vs endovascular reapir of abdominal aortic aneurysm: results of a multicenter randomized trial. J Vasc Surg. 2012;56(4):901-2. PMid:22640466. http://dx.doi. org/10.1016/j.jvs.2012.01.086

22. Becquemin JP, Pillet JC, Lescalie F, Sapoval M, Goueffic Y, Lermusiaux $P$, et al. A randomized controlled trial of endovascular aneurysm repair versus open surgery for abdominal aortic aneurysms in low to moderate risk patients. J Vasc Surg. 2011;53(5):1167-73. PMid:21276681. http://dx.doi.org/10.1016/j. jvs.2010.10.124

23. Greenberg RK, Chuter TA, Cambria RP, Sternbergh WC, Fearnot NE. Zenith abdominal aortic aneurysm endovascular graft. J Vasc Surg. 2008;48(1):1-9. PMid:18486418. http://dx.doi.org/10.1016/j. jvs.2008.02.051

24. Hogg ME, Morasch MD, Park T, Flannery WD, Makaroun MS, Cho JS. Long-term sac behavior after endovascular abdominal aortic aneurysm repair with excluder low-permeability endo prosthesis. J Vasc Surg. 2011;53(5):1178-83. PMid:21276679. http://dx.doi. org/10.1016/j.jvs.2010.11.045

25. Veith FJ. How can good randomized controlled trials in leading journals be so misinterpreted? J Vasc Surg. 2013;57(2):3S-7S. PMid:23336854. http://dx.doi.org/10.1016/j.jvs.2012.04.076

26. Bredahl K, Long A, Taudorf $M$, Lönn L, Rouet L, Ardon R, et al. Volume estimation of the aortic sac after EVAR using 3-D ultrasound e a novel, accurate and promising technique. Eur J Vasc Endovasc Surg. 2013;45(5):450-5. PMid:23433497. http:// dx.doi.org/10.1016/j.ejvs.2012.12.018

27. Causey MW, Jayaraj A, Leotta DF, Paun M, Beach KW, Kohler TR, et al. Three-Dimensional ultrasonography measurements after endovascular aneurysm repair. Ann Vasc Surg. 2013;27(2):146-53. PMid:22749436. http://dx.doi.org/10.1016/j.avsg.2012.01.018

28. Zandvoort HJA, Gonçalves FB, Verhagen HJM, Moll FL, Vries JPPM de, Van Herwaarden JA. Results of endovascular repair of infrarenal aortic aneurysms using the Endurant stent graft. J Vasc Surg. 2014;59(5):1195-202. PMid:24433782. http://dx.doi. org/10.1016/j.jvs.2013.12.031

29. Cao P, Rango P de, Verzini F, Parlani G, Romano L, Cieri E, et al. Comparison of surveillance versus aortic endografting for small aneurysm repair (CAESAR): results from a randomised trial. Eur J Vasc Endovasc Surg. 2011;41(1):13-25. PMid:20869890. http:// dx.doi.org/10.1016/j.ejvs.2010.08.026

30. Silva ES, Hanaoka MH, Puech-Leão P, Tolosa EMC. Relação morfológica entre o diâmetro, o colo proximal e distal dos aneurismas da aorta abdominal. J Vasc Br. 2004;3:95-101.

31. Ashton HA, Buxton MJ, Day NE, Kim LG, Marteau TM, Scott RA, et al. The Multicentre Aneurysm Screening Study (MASS) into the effect of abdominal aortic aneurysm screening on mortality in men: a randomised trial. Lancet. 2002;360(16):1531-9. PMid:12443589.

32. Scott RAP. The multicentre aneurysm screening study (MASS) into the effect of abdominal aortic aneurysm screening on mortality in men: a randomised trial. Lancet. 2002;360(9345):1531-9. http:// dx.doi.org/10.1016/S0140-6736(02)11522-4
33. Humphries MD, Suckow BD, Binks JT, McAdam-Marx C, Kraiss LW. EVAR continues to cost more than open repair. J Vasc Surg. 2013;58(2):563. http://dx.doi.org/10.1016/j.jvs.2013.05.075

34. Silva ES, Rodrigues AJ Jr, Rodrigues CJ, Tolosa EMC, Prado GVB, Nakamoto JC. Morphology and diameter of infrarenal aortic aneurysms: a prospective autopsy study. Cardiovasc Surg. 2000;8(7):526-32. http://dx.doi.org/10.1016/ S0967-2109(00)00060-0

35. Fillinger MF, Raghavan ML, Marra SP, Cronenwett JL, Kennedy FE. In vivo analysis of mechanical wall stress and abdominal aortic aneururysm rupture risk. J Vasc Surg 2002;36(3):589-97. http:// dx.doi.org/10.1067/mva.2002.125478

36. Fillinger MF, Marra SP, Raghavan ML, Cronenwett JL, Kennedy FE. Prediction of rupture risk in abdominal aortic aneurysm during observation: wall stress versus diameter. J Vasc Surg. 2003;37(4):724-32. PMid:12663969. http://dx.doi.org/10.1067/ mva.2003.213

37. Raghavan ML, Hanaoka MM, Kratzberg JA, Higuchi ML, Silva ES $\mathrm{da}$, Biomechanical failure properties and microstructural content of ruptured and unruptured abdominal aortic aneurysms. J. Biomechanics. 2011:44(13):2501-7. PMid:21763659. http://dx.doi. org/10.1016/j.jbiomech.2011.06.004

38. Raghavan ML, Kratzberg J, Tolosa EMC, Hanaoka MM, Walker $P$, Silva ES da. Regional distribution of wall thickness and failure properties of human abdominal aortic aneurysm. J. Biomechanics 2006:39(16):3010-6. PMid:16337949. http://dx.doi.org/10.1016/j. jbiomech.2005.10.021

39. Vorp DA, Mandarino WA, Webster MW, Gorcsan III J. Potential influence of intraluminal thrombus on abdominal aortic aneurysm as assessed by a new non-invasive method. Cardiovasc Surg. 1996;4(6):732-9. http://dx.doi.org/10.1016/ S0967-2109(96)00008-7

40. Lindholt JS, Heickendorff L, Henneberg EW, Fasting H. Serumelastin-peptides as a factor of expansion of small abdominal aortic aneurysms. Eur J Vasc Endovasc Surg. 1997;14(1):12-6. http:// dx.doi.org/10.1016/S1078-5884(97)80219-5

41. Tilson MD, Newman K. Rationale for molecular approaches to the etioloy of abdominal aortic aneurysm disease. J Vasc Surg. 1992;15(5):924-5. http://dx.doi. org/10.1016/0741-5214(92)90753-U

Correspondence Erasmo Simão da Silva Rua Martins, 96 - Butantã CEP 05511-000 - São Paulo (SP), Brazil E-mail:ersimao@usp.br

Author information

ESS é Livre Docente da Disciplina de Cirurgia Vascular e Endovascular da Faculdade de Medicina da Universidade de São Paulo (USP). 